\title{
A NOVEL CONCEPT FOR QUANTITATIVE MEASUREMENT OF ORGANIZATIONAL PERFORMANCE INDEX
}

\author{
UDC: 658.5 \\ 005.35 \\ Original Scientific Paper \\ Simon K. JOHN ${ }^{1}$, Samuel P. MATHEWS ${ }^{1}$, Balachandra P. SHETTY ${ }^{2}$, R. K. MISHRA ${ }^{3}$ \\ ${ }^{1}$ Regional Centre for Military Airworthiness (Engines), Bangalore 560093, India \\ ${ }^{2}$ Department of Mechanical Engineering, Nitte Meenakshi Institute of Technology, Yelahanka, \\ Bangalore 560064, India \\ ${ }^{3}$ Regional Centre for Military Airworthiness (Engines), Bangalore 560093, India \\ E-mail: rkmishra.drdo@gmail.com
}

Paper received: 15.06.2020.; Paper accepted: 16.07.2020.

\begin{abstract}
The performance of an organization depends on many dimensions of technology and management such as leadership, strategic planning, customer focus, process management, measurement, analysis, knowledge management, costing, financial management, and human resource management. However, the efficiency of the organization can be easily assessed from the organization's performance output compared to the set targets while other dimensions act as addon catalysts in maximizing productivity. Hence, the measurement of the overall output of the organization as well as all its departments in any organizational hierarchy becomes very critical. A novel quantitative measurement methodology of the organizational output combining mathematical and statistical modeling on the bottoms-up approach is developed and explained in this paper. The concept can be used with existing enterprise resources and planning tools available in industries for the enhancement of their productivity.
\end{abstract}

Keywords: Work Output Values; Production Planning Control; Performance Index; Division of the task; Weightage factor.

\section{INTRODUCTION}

An organization works with a set of visions, goals, roles, and objectives for its existence in its prevailing eco-environmental system. These aspects are clearly laid down in its ethos, policy guidelines, and quality manuals. The uniqueness of any organization can be built on four pillars of management, namely, customer focus, total participation, continuous improvement, and societal networking (Brown, 2017; Graham, Shiba, $\&$ Walden, 2001). These aspects generally translate into the role and objectives of the organization. Role and objectives are generally broken up into targets and tasks set over a specific period in consideration. This data forms the basis for performance achievement and comparison of work output over a similar period or for a similar task completed at some other time. Usually, a period of one year is taken for this purpose and further split into different segments, generally on quarterly mode for assessment of any company's overall performance.

The balanced scorecard philosophy also talks about the performance measurement of an organization on a top-down approach covering most of the organizational dimensions (Monks, 1987). However, the target accomplishment is the only performance dimension that is visible or tangible to all the stakeholders for assessing the health of the organization. In other words, a task accomplished over a period against the set targets indicates performance. For an accurate and unbiased understanding of how an organization is performing in its competitive environment, a quantitative and accurate measurement of the task or output is very critical. 
For assessing the task or target assigned to any organization accurately and quantitatively, it is very important to perform task measurement on the lines of a functional hierarchy of the organization starting from the lowest workgroup to the company topmost management level. Otherwise, it can lead to a skewed reflection of organizational performance for the period in consideration. Hence any performance measurement of an organization should encompass its various departments and workgroups depending on the organizational structure which becomes very vital in the performance assessment. By this means, the management can clearly visualize the achievers and the laggards for any rewards or for instituting any remedial measures.

The production planning and control system that exists in any industrial organization highlights the vitality of accurately measuring the output but does not give a clear methodology for measuring it for its various departments and workgroups (Nair, 2004). Hence, precocious manpower resources are used only for progress monitoring. An online work out performance assessment in quantitative terms can address this issue to a greater extent. A methodology for an online accurate quantitative task output measurement of the period in consideration (Zhao, Morita, \& Maruyama, 2019) can solve these cumbersome manual progress monitoring systems existing in some type of organizations such as in an Aviation Maintenance Repair and Overhaul (MRO) and Production Industry. For this type of organisation, a mathematical cum statistical model has been evolved and is presented in this paper which can form the basis for an online quantitative output performance monitoring system (Anderson, 1985). This model can be further extended for developing a resource planning tool for various entrepreneurs. The current model is developed keeping various factors of aviation MRO and Production Industry, thereby assigning various weightage factors on parameters encountered in this field. As the actual data is of proprietary nature, an exercise based on simulated data is compiled to understand the measurement of work output against the set target each workgroup and department is carried out and converted on a quantitative scale.

\section{MODEL PARAMETERS}

A model is developed based on the organizational structure of an aviation MRO and Production industry. Therefore, understanding the organizational structure of the industry is very important which has been presented in Figure 1 (Balaboniene, \& Vecerskiene, 2015; Spekle, \& Verbeeten, 2014). The staff function departments are positioned horizontally on the organization structure while the line function departments and their work sections are positioned in verticals. Major work sections are divided into sections and sub-sections which further consist of workgroups, project groups, manufacturing shop, etc. based on the role and criticality of the work sections/subsections.

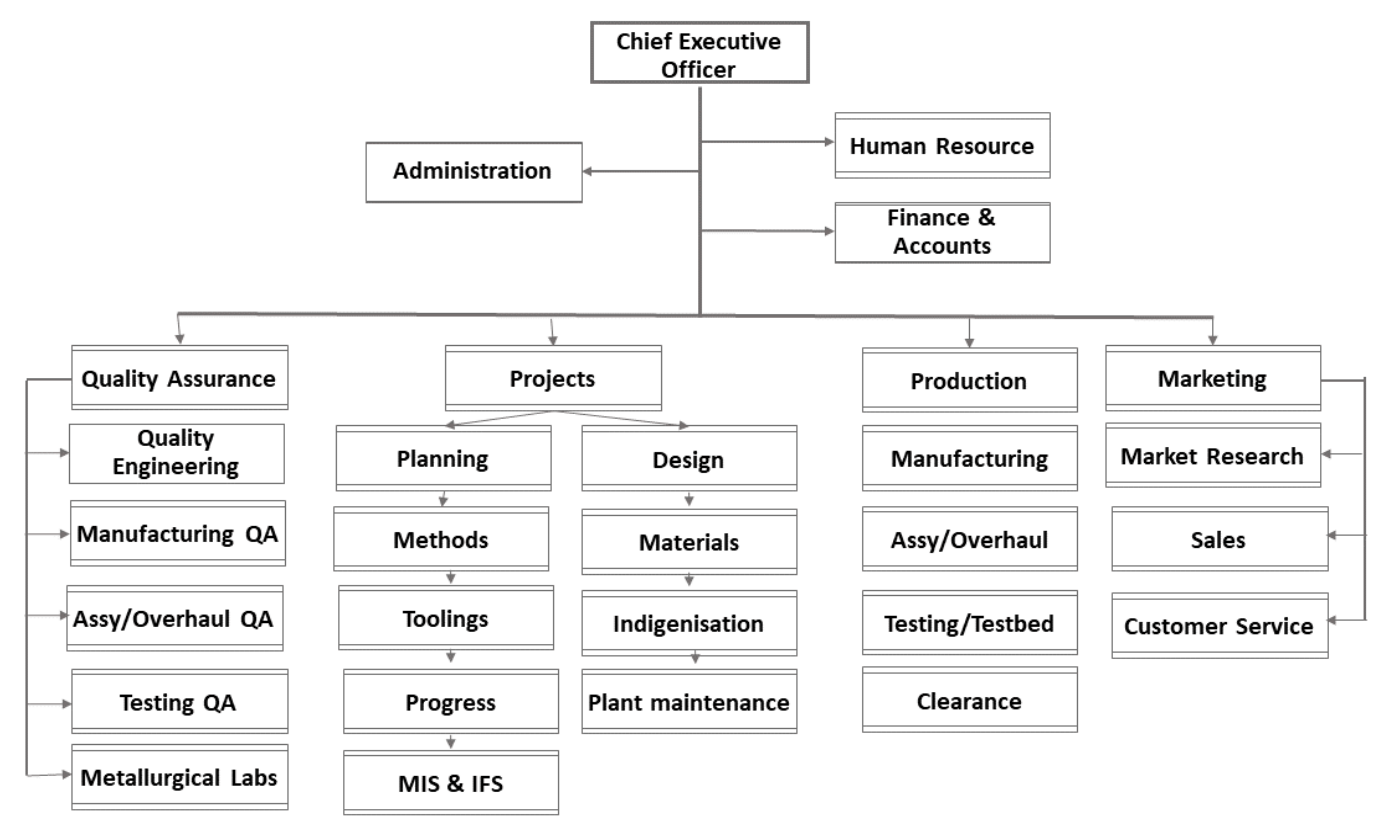

Figure 1: Organization Structure of a Typical Aviation MRO 
In a department or division, different types of tasks are handled by the workgroups, sections, and subsections under that department. Tasks can be of product or processes or service-oriented. Timely completion of the tasks eventually leads to the accomplishment of targets set by the division through the production and aggregate planning process. These tasks can be broadly classified into three types, i.e. routine tasks, unscheduled tasks, and special assignments. A brief on these tasks is narrated in this section (Anderson, 1985; Bonabeau, Sobkowski, Theraulaz, \& Deneubourg, 1997).

\section{Classification of Tasks}

\section{Routine Task}

The task is executed on a regular or repetitive basis assigned by the company. It may be noted here that the time period of the subjected task may vary depending on the overall production task of the organization. For the measurement of such tasks, priorities need to be classified, such as high priority, medium priority, and low priority tasks. The priorities have to be decided by the top management. Since these priority tasks require a proportionate weightage while computing the work output in measurable terms, the same lines followed in $\mathrm{ABC}$ classifications of inventory management is applied, i.e., high priority task assumes a weightage of $60 \%$, medium priority will have a $30 \%$ weightage and low priority will have the balance $10 \%$ towards weighted averaging of work output of various tasks (Braglia, Grassi, \& Montanari, 2004; Zhou, 2013).

\section{Un-scheduled Tasks}

These tasks are non-regular and occasional in nature, but the nature of work quantum and a proper schedule and process can be established. Such tasks cannot be planned in a normal production planning control or aggregate planning stages and such tasks do occur unexpectedly. Examples can be like recovery of an aircraft or an aero-engine using on-site repair or maintenance, or even an accident investigation.

\section{Special Assignments}

The special assignment is a form of a one-time task but not confined to the lowest work or project group. Here multiple groups or sections or even departments join together in a matrix form in undertaking the task. Hence work output value cannot be given to any workgroup and instead it is given to the section or the department or even to the whole division depending upon the criticality, operational spread, and nature of these special assignments. Some of the examples of such tasks are seminar conduct, event management like air display, product exhibition, an undertaking of corporate social activities wherein more than one workgroups or sections or departments or even whole division combines to make it a success for goodwill development of the organization.

\section{Weightage Factors}

Assignment of weightage factors for various types of tasks plays an important role in the computation of performance index for various workgroups, shops, sections, and departments and the overall industry (Melnyk, et al., 2014). The concept of the weightage factor is presented in the following paragraphs.

\section{Weightage factors for Tasks}

Weightage factors are assigned to various tasks for quantification of the tasks based on priority. High priority task (priority-1) assumes a weightage of $60 \%$, medium priority (priority-2) will have 30\% weightage and low priority (priority-3) will have the balance of $10 \%$ towards weighted averaging of work output. The well-known ABC inventory analysis approach has been adopted here for this weightage concept (Teunter, Babai, \& Syntetos, 2010). Similarly, weightage factors between routine tasks and one-time tasks are set as $80 \%$ : $20 \%$. This $20 \%$ is tailored to take into account of minimum three tasks with a maximum of $20 \%$ weightage given for a high priority one time task while a medium priority one-time task can of $10 \%$ and a low priority one-time task can be given 5\% weightage. For example when a low-priority unscheduled task is undertaken by a workgroup, then the weightage between the scheduled and unscheduled task of the group will be 95\%:05\% and so on. Further, even if more than one type of unscheduled task comes to the workgroup during the quarter, the maximum weightage factor will be of $20 \%$ only. The priorities of the tasks have to be given by the production planning department of the company well before the commencement of the job by the workgroups.

In the case of special assignments, priority 1, 2, and 3 can be set in the ratio of 10,5 , and 3 
percentages with a maximum weightage ceiling of $18 \%$. These can be added at the appropriate levels of the functional hierarchy (Melnyk et al., 2014; Teunter, Babai, \& Syntetos, 2010). Priorities of all types of tasks have been arrived based on the quantum of these unscheduled and special tasks that are assigned to work stations and sections/departments following the Delphi approach.

\section{Weightage factors for Departments/Work Groups}

Weightage factors for departments and workgroups have been arrived based on standard practices followed in Military Aviation MRO Industries which are as follows:

$\begin{array}{ll}\text { Production } & : 30 \% \\ \text { Planning \& Progress } & : 25 \% \\ \text { Quality assurance } & : 20 \% \\ \text { Marketing } & : 15 \% \\ \text { Finance \& accounts } & : 6 \% \\ \text { Administration } & : 2 \% \\ \text { HR } & : 2 \% .\end{array}$

On the same lines, weightage factors have been derived for sections under each department and the workgroup in each section. However, the weightage factors of various departments can vary depending on the nature of industries (Kennedy et al., 2020; Li, Etienne, Vernadat, \& Siadat, 2018).

Objective assessment of weightage factors is a critical aspect for calculation of output performance numbers which can truly reflect the output efficiency and effectiveness of various workgroups, sections, and departments.

\section{METHODOLOGY FOR COMPUTATION OF WORK OUTPUT VALUES}

The foremost aspect of measuring a task assigned to the work or project group is the computation of the work output values (WOV) for each type of task. Based on the priority and weights assigned to these tasks, a research hypothesis of WOV can be evolved. Methodology for computation of work output values for a project group is schematically shown in figure 2 for better appreciation.

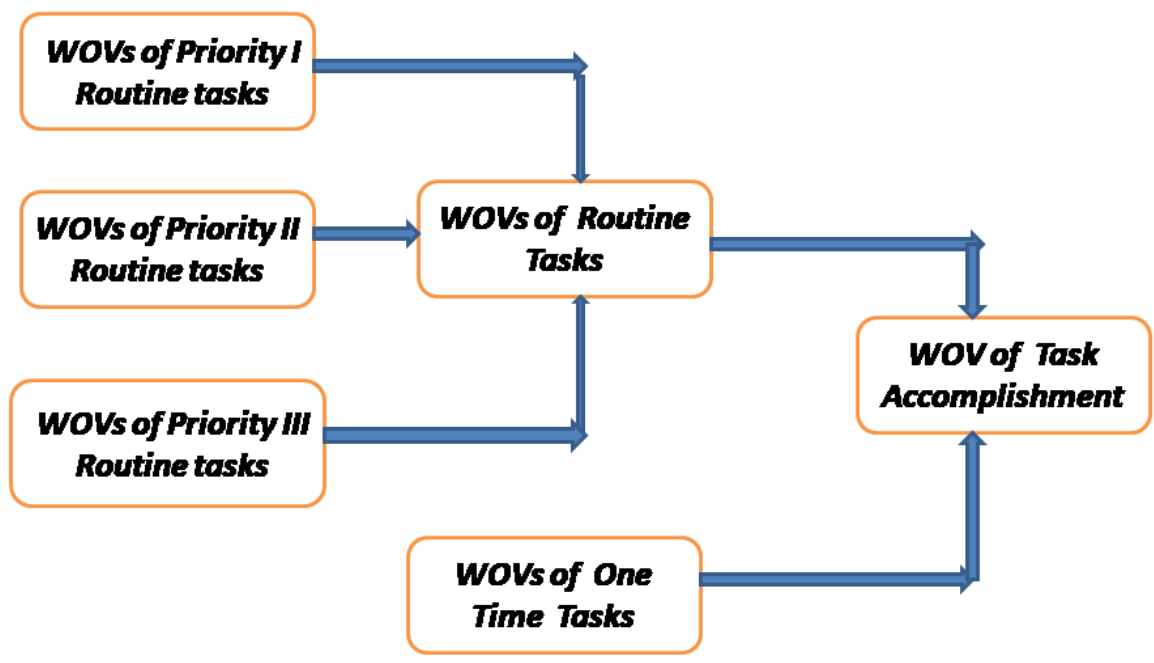

Figure 2: Flow Chart of WOV Computation of Tasks

Hypothesis for Work Output Computation (Richard, Devinney, Yip, \& Johnson, 2009;

Stanleigh, 2015).

It may be noted that the task completion or accomplishment of the workgroup is the total work output values of all types of tasks during the quarter or over a period in consideration.

Let there are be $n_{1}, n_{2}$, and $n_{3}$ number of jobs for priority 1 , priority 2 , and priority 3 tasks, then the task output values for these tasks can be estimated as:

$$
T_{1 r}=T_{11}+T_{12}+T_{13}+\ldots+T_{1 n_{1}}=\frac{\sum_{\mathrm{r}=1}^{\mathrm{n}} \mathrm{T}_{1 r}}{\mathrm{n}_{1}}
$$

where $t_{r 1}$ to $t_{r n}$ is the $n$ different routine tasks values of priority $i$ jobs. On the application of the weightage factor, the Value of Priority 1 jobs 


$$
T_{1 r}=\frac{w f t_{r 1} \sum_{\mathrm{r}=1}^{\mathrm{n}} \mathrm{T}_{1 r}}{\mathrm{n}_{1}}=\frac{0.6 \sum_{\mathrm{r}=1}^{\mathrm{n}} \mathrm{T}_{1 r}}{\mathrm{n}_{1}}
$$

Similarly, the Value of Priority 2 routine task is

$$
T_{2 r}=\frac{w f t_{r 2} \sum_{\mathrm{r}=1}^{\mathrm{n}} \mathrm{T}_{2 r}}{\mathrm{n}_{2}}=\frac{0.3 \sum_{\mathrm{r}=1}^{\mathrm{n}} \mathrm{T}_{2 r}}{\mathrm{n}_{2}}
$$

and Value of Priority 3 routine task is

$$
T_{3 r}=\frac{w f t_{r 3} \sum_{\mathrm{r}=1}^{\mathrm{n}} \mathrm{T}_{3 r}}{\mathrm{n}_{3}}=\frac{0.1 \sum_{\mathrm{r}=1}^{\mathrm{n}} \mathrm{T}_{3 r}}{\mathrm{n}_{3}}
$$

The total value of the routine task

$$
T_{r}=0.8\left[\frac{0.6 \sum_{\mathrm{r}=1}^{\mathrm{n}} \mathrm{T}_{1 r}}{\mathrm{n}_{1}}+\frac{0.3 \sum_{\mathrm{r}=1}^{\mathrm{n}} \mathrm{T}_{2 r}}{\mathrm{n}_{2}}+\frac{0.1 \sum_{\mathrm{r}=1}^{\mathrm{n}} \mathrm{T}_{3 r}}{\mathrm{n}_{3}}\right]
$$

and value for unscheduled or one-time jobs is

$$
T_{o t}=\frac{w f t_{o t} \sum_{o t=1}^{\mathrm{n}} \mathrm{T}_{1 o t}}{N_{o t}}=\frac{0.2 \sum_{o t=1}^{\mathrm{n}} \mathrm{T}_{1 o t}}{N_{o t}}
$$

where $N_{o t}$ is the number of one-time jobs and $w f t_{r 1}, w f t_{r 2}, w f t_{r 3}$ and $w f t_{o t}$ are the weightage factors of priority 1, 2, and 3 and one-time task respectively.

Total Work Output Value or WOV of all Tasks will be the sum of

Value of Routine tasks + Value of one-time tasks $=\left[\mathrm{T}_{r}+\mathrm{T}_{o t}\right]$

When no one-time task existed, the total task output value will be $\sum \mathrm{T}_{r}$ only.

\section{Scaling Techniques for Job Completion}

Scale Values (SV) are required to be arrived for converting the work completion time for the assigned period of time. This is done by assigning suitable Work Output Values (WOV) based on work Rule $W_{i j}=\frac{t_{i}}{T_{i}}$ where $\mathrm{T}$ is the assigned time for the task, $\mathrm{t}$ the time taken to complete the task and $\mathrm{t}<\mathrm{T}$, $\mathrm{i}$ number of completed jobs and $j$ number of tasks (Garg, Karadia, Agarwal, 2002).
Rating is done on a one pointer scale with zero as minimum and 1.25 as the maximum. Scaling methodology evolved from standard research methodology approaches (Kothari, 1990) are shown below:

\section{For Routine or Scheduled Jobs}

1) Job completion in $<80 \%$ of the

1) time frame assigned $=1.25$

2) Completion between 80 to $100=1.1$

3) Job completion in an assigned $\quad=1.0$
time frame

$\begin{aligned} & \text { 4ob completion in } 110 \% \text { of the } \\ & \text { time frame assigned }\end{aligned}=0.9$

5) Job completion in $125 \%$ of time $=0.8$
frame assigned

6) Job completion in $150 \%$ of the $=0.7$

7) The job takes more than $150 \%=0.5$

8) The job took double the time or $=0.25$

9) Job not completed $=0.0$

For Unscheduled or One Time Jobs $(o)$
1) Completion before Time
$=1.25$
2) Completion in Time
$=1.0$
3) Time takes up to $125 \%$
$=0.75$
4) Takes time $>125 \%$
$=0.5$
5) Non-Completion of job
$=0.0$

For Short time (one/two-man day) Jobs
1) Completion in time
$=1.0$
2) Completion in one-week
$=0.5$
3) More than one-week time
$=0.25$
4) Non-Completion of Task
$=0.0$

\section{Rules and Boundary Conditions for Measurement}

Before applying these scaling methodologies for calculating the WOV, the following general guidelines or conventions should be adopted:

1) The nature of tasks of each project/machine shop/work-section should be clearly written for creating a basic task data bank for each workgroup and section. Based on this, the required data input forms can be designed.

2) Manufacturing shops will have multiple jobs and hence task has to be given priority for computation of WOVs of the task completion followed by averaging the WOV's of all the parts under the same category and then weighted averaging across priority categories 
for arriving the final task completion value of the lowest workgroup or shop or subsection (Dose, 1997; Hartnell, Ou, \& Kinicki, 2011).

3) Department or section which involves the assembly of major products like aircraft, helicopters, aero engines, payloads, etc., number of these major parts assembled against the set target will be the basis of task measurement.

4) Even though production data entry to the system wherever manual data entry is still in practice, takes place at a certain time interval, task completion value or WOV indexing shall be carried out quarterly.

5) As the weightage of priority I, II, and III jobs are in the ratio of $60 \%: 30 \%: 10 \%$, job quantum is taken such that one major job is equated with two medium jobs and four minor jobs in the ratio of 1:2:4 for getting these weightages. Where no major jobs and only minor and medium jobs exist, weightages shall be in proportion of $67 \%: 33 \%$. If no priority III job exists, then weightages will be in proportion of 67\%:33\% and if no priority II job exists then the ratio will be $75 \%: 25 \%$ between priority I \& III jobs.

\section{Scaling Methodology of Special Assignments}

When a special assignment is given for any division or department, this has to be completed either against a cut-off-date or within a time frame allotted. Wherever time frame is the criteria, the scaling methodology explained above can be adopted. But when a special task is to be completed against a cut-off-date then opinions on the task completion in terms of quality and time adherence of the work completed can be taken from the Corporate Head. The opinions and their SVs on a ten-point scale are provided in the following lines:
1) For Exceptional
$: \mathrm{SV}=11.0 / 1.1$
2) For Excellent
$: \mathrm{SV}=10.0 / 1.0$
3) Highly satisfactory
$: \mathrm{SV}=8.0 / 0.8$
4) Satisfactory
$: \mathrm{SV}=7.0 / 0.7$
5) For Average
$: \mathrm{SV}=6.0 / 0.6$
6) For Below average
$: \mathrm{SV}=5.0 / 0.5$
7) Job not completed
$: \mathrm{SV}=0.0$

\section{Guidelines for Special Assignment}

Guidelines required to be adopted/adhered to while measuring the WOV of special Assignments are on the following lines.
1) Weightage for special assessment shall not exceed 18\% when multiple special jobs are assigned and completed in the same quarter of the year with different priority assignments

2) Special assignment priorities shall carry $10 \%$ for high priority, $6 \%$ for medium priority, and $2 \%$ for low priority tasks. WOV for up to 03 special assignments only shall be counted for a period of counting.

3) First, department/section WOV shall be evolved by weighted averaging of all workgroups WOV's and then special assignment performance index shall be added if a special assignment is given to that section (Dose, 1997; Hartnell, Ou, \& Kinicki, 2011).

4) For the special assignment of a division, a full of $18 \%$ weightage shall be added. Also, if some one-time special assignments are completed in one quarter are of top priority, then the $18 \%$ weightage will be divided equally between these assignments.

5) Duration of special assignments can vary from within a quarter to even for a year. In such cases, a special assignment that is scheduled to be completed within the quarter shall get the full weightage as per priority.

6) Any special assignment which takes more than thrice the time frame allotted shall be considered as a job not done and a value of zero has to be counted in the WOV calculations of the affected section/departments.

\section{Calculation of Department-wise Performance Index}

WOV index numbers are computed for the lowest workgroups/shops/project groups of all the sections for the assigned time period. From these WOV index numbers of its sections, index numbers for departments, and finally for the division can be computed. WOVs of the period in consideration for all the lowest workgroups/shops/projects are computed based on these methodologies explained above and are built upwards on a weighted average principle to their sections, departments, and finally to the division. Since any production planning and control (PPC) progress is made on yearly basis and aggregated to quarterly mode, these WOV numbers are estimated on a quarterly mode like the normal econometric indices' computation. The four-quarter numbers of the workgroups, subsections, sections, departments, and divisions are averaged for getting the annual performance index of the division. These numbers are given on a 10 point-scale and 
accordingly, all the groups and organizational structural hierarchy can be rated for understanding the performance ratings of the sections (Gross, 2015; Waggoner, Neely, \& Kennerley, 1999).

\section{Performance Ratings of Work Accomplishment}

Appropriate performance ratings on a 10 point scale can be evolved once the WOV index numbers arrived for various workgroups, sections, departments, and divisions. These ratings can be on the following lines:

$\begin{array}{lll}\text { 1) } & \text { Exceptional } & \geq 9.0 \\ \text { 2) } \text { Outstanding } & \geq 8.5 \\ \text { 3) } & \text { Excellent } & \geq 8.0 \\ \text { 4) Highly Satisfactory } & \geq 7.5 \\ \text { 5) Satisfactory } & \geq 7.0 \\ \text { 6) Average } & \geq 6.0 \\ \text { 7) } & \text { Below Average } & <6.0\end{array}$

These ratings have been evolved based on the conventional Inspection and Audit rating techniques followed in Military Aviation MRO industries which are generally unpublished and proprietary in nature. It has been observed that various work stations and sections generally tend to satisfy the task with a performance index above 7.

The said model is built up based on the production planning done by the planning department after assessing all the resources of men, material and machinery, and other aspects if can be visualized. However in case, the performance is hampered for any unforeseen events like machine breakdown or company lockdown, then it gets reflected in the performance index along with an output report with a reason for not achieving the targets. If for lack of skilled manpower it happens, then it is a reflection of the bad capacity planning wherein the planning department should have taken into account these aspects before the aggregate and master production planning is worked out.

\section{RESULTS AND DISCUSSION}

The computation of the performance index is carried out with an example of a manufacturing shop where 10 routine tasks have been assigned by the planning department for a specific quarter of a year. Out of the tasks, three tasks are of low priority, 5 of medium priority, and the remaining 02 tasks are of high priority. Besides, 03 one-time tasks (one low, one medium, and one high priority) are also loaded during this quarter. Details of the job completion of these tasks captured either manually or by a dynamic data capture system is presented here along with the Work Output Value (WOV).

\section{High Priority Tasks}

- $1^{\text {st }}$ job completed within $90 \%$ of the time allotted 7 and thus WOV is 1.1 ;

- $2^{\text {nd }}$ job took $10 \%$ more time than the allotted time and WOV is 0.9 .

\section{Medium Priority Tasks}

- $1^{\text {st }}$ job completed within $80 \%$ of the time allotted and WOV is 1.25 ;

- $2^{\text {nd }}$ job completed as per the time allotted and WOV is $=1.0$ );

$-3^{\text {rd }}$ job took $10 \%$ more time than the allotted time and WOV is 0.9 ;

$-4^{\text {th }}$ job took $25 \%$ than the allotted time (WOV=0.8);

- $5^{\text {th }}$ job could not be completed and WOV is 0 .

\section{Low priority Tasks}

- $1^{\text {st }}$ job completes as per time allotted and WOV is 1.0 ;

$-2^{\text {nd }}$ job completed within $90 \%$ of the time allotted and WOV is 1.1;

$-3^{\text {rd }}$ job took $50 \%$ extra time than allotted and WOV is 0.5 .

\section{One Time Tasks}

$-1^{\text {st }}$ job completed with $80 \%$ of the allotted time and WOV is 1.25 ;

$-2^{\text {nd }}$ job took $10 \%$ more time than allotted and WOV is 0.75 ;

$-3^{\text {rd }}$ job took $50 \%$ extra time than allotted and WOV is 0.5 .

In case each job consists of batches, then averaging or percentage completion of the batch is taken for assessing the WOV. The computation of Work Output Value (WOV) Index numbers of the workgroup can be made as follows: 
1)

Average WOV of

priority 1 tasks

2)

WOV of priority 2 tasks

3)

WOV of priority 3
tasks

4)

Average WOV of

Unscheduled jobs

$$
T_{1 r}=\frac{w f t_{r 1} \sum_{\mathrm{r}=1}^{\mathrm{n}} \mathrm{T}_{1 r}}{\mathrm{n}_{1}}=\frac{0.6(1.1+0.9)}{2}=0.6
$$$$
T_{2 r}=\frac{w f t_{r 2} \sum_{\mathrm{r}=1}^{\mathrm{n}} \mathrm{T}_{2 r}}{\mathrm{n}_{2}}=\frac{0.3(1.25+1.0+0.9+0.8+0)}{5}=0.243
$$$$
T_{3 r}=\frac{w f t_{r 3} \sum_{\mathrm{r}=1}^{\mathrm{n}} \mathrm{T}_{3 r}}{\mathrm{n}_{3}}=\frac{0.1(1.0+1.1+0.5)}{3}=0.0867
$$

$$
T_{o t}=\frac{w f t_{o t} \sum_{o t=1}^{\mathrm{n}} \mathrm{T}_{o t}}{\mathrm{n}_{o t}}=\frac{0.2(1.27+0.75+0.5)}{3}=0.168
$$

The Average WOV index number of the Shop is then estimated by:

$$
\begin{aligned}
& T_{S}=w f_{t r}\left(\frac{w f t_{r 1} \sum_{\mathrm{r}=1}^{\mathrm{n}} \mathrm{T}_{1 r}}{\mathrm{n}_{1}}+\frac{w f t_{r 2} \sum_{\mathrm{r}=1}^{\mathrm{n}} \mathrm{T}_{2 r}}{\mathrm{n}_{2}}+\frac{w f t_{r 3} \sum_{\mathrm{r}=1}^{\mathrm{n}} \mathrm{T}_{3 r}}{\mathrm{n}_{3}}\right)+\frac{w f t_{o t} \sum_{o t=1}^{\mathrm{n}} \mathrm{T}_{o t}}{\mathrm{n}_{o t}}= \\
& =0.8(0.6+0.243+0.0867)+0.168=\mathbf{0 . 7 4 3 8}+\mathbf{0 . 1 6 8}=\mathbf{0 . 9 1 2} \text { or } \mathbf{9 . 1 2} .
\end{aligned}
$$

On a similar line, it is possible to compute the WOV index numbers of all the lowest workgroups like machine shops, project groups, or workgroups of the section or subsection, time frame for completion of the tasks on the assigned time period can be taken quarterly. However, for this purpose, each section, subsection, and workgroups should clearly list down various types of tasks and with available resources and should form the database needed for computation. The tasks can be the product, process, or even services being rendered by the workgroups and its sections.

Now for an example, let us consider a Section consisting of ten work centres. The WOV index number and their weightage factors for these work centres are presented in table 1 . It may be noted that weightage factors for these work centres are to be assigned by the Divisional management-based criteria like criticality of the project/work, the quantum of task loaded on these centres in terms of money and target set.

Now the net quarterly WOV index numbers are estimated to be 7.3865 as presented in table 1 for the said section for one quarter of the year. Based on this index number, it can be judged that the performance of the section in the particular quarter is Satisfactory.

Similarly, the performance of a department having five sections can be estimated as presented in table 2 . The output performance value of the department for the relevant quarter is found to be $\mathbf{7 . 6 2}$ and the output performance of the department can be considered as Highly Satisfactory.

Table 1: WOV Index Number Estimation for a Section: an example

\begin{tabular}{|c|c|c|c|}
\hline $\begin{array}{c}\text { Work } \\
\text { Centre } \\
\text { No. }\end{array}$ & WOV & $\begin{array}{c}\text { Weightage } \\
(\boldsymbol{\%})\end{array}$ & WOV.Weightage \\
\hline 1 & 7.15 & 15 & 1.0725 \\
\hline 2 & 6.60 & 25 & 1.65 \\
\hline 3 & 7.61 & 10 & 0.761 \\
\hline 4 & 8.30 & 15 & 1.245 \\
\hline 5 & 7.31 & 5 & 0.3655 \\
\hline 6 & 7.25 & 10 & 0.725 \\
\hline 7 & 6.80 & 5 & 0.340 \\
\hline 8 & 8.75 & 5 & 0.4375 \\
\hline 9 & 7.80 & 5 & 0.39 \\
\hline 10 & 8.20 & 5 & 0.41 \\
\hline $\begin{array}{l}\mid l \\
\text { SeV index of the }\end{array}$ (WOV.Weightage) & $\mathbf{7 . 3 8 6 5}$ \\
\hline
\end{tabular}

Table 2: WOV Index Number Estimation for a Department: an example

\begin{tabular}{|c|c|c|c|}
\hline $\begin{array}{c}\text { Section } \\
\text { No. }\end{array}$ & WOV & $\begin{array}{c}\text { Weightage } \\
(\%)\end{array}$ & WOV.Weightage \\
\hline 1 & 6.85 & 15 & 1.0275 \\
\hline 2 & 7.41 & 10 & 0.741 \\
\hline 3 & 7.60 & 20 & 1.52 \\
\hline 4 & 8.30 & 30 & 2.49 \\
\hline 5 & 7.35 & 25 & 1.8375 \\
\hline $\begin{array}{l}\text { WOV index of the } \\
\text { Department }=\sum \text { (WOV.Weightage) }\end{array}$ & 7.616 \\
\hline
\end{tabular}


Coming to the organization level of a typical Aviation MRO and Production Industry, weightage factors and WOVs of various departments can be assigned as per industry norms or as per requirements and the output performance index value of the organization can be estimated as presented in table 3 . The output performance index value for the organization or Division for the quarter is found to be 7.511 which is considered as Highly Satisfactory.

Table 3: WOV Index Number Estimation for a Division or Organization: an example

\begin{tabular}{|l|c|c|c|}
\hline Department & WOV & $\begin{array}{c}\text { Weightage } \\
(\%)\end{array}$ & WOV· Weightage \\
\hline Production & 7.62 & 30 & 2.286 \\
\hline $\begin{array}{l}\text { Planning \& } \\
\text { project }\end{array}$ & 7.36 & 25 & 1.84 \\
\hline $\begin{array}{l}\text { Quality } \\
\text { assurance }\end{array}$ & 7.50 & 20 & 1.50 \\
\hline Marketing & 8.00 & 15 & 1.20 \\
\hline $\begin{array}{l}\text { Finance \& } \\
\text { Accounts }\end{array}$ & 6.85 & 6 & 0.411 \\
\hline Admiration & 7.00 & 2 & 0.14 \\
\hline HR & 7.00 & 2 & 0.14 \\
\hline $\begin{array}{l}\text { WOV index of the } \\
\text { Division= }=\text { (WOV·Weightage) }\end{array}$ & 7.511 \\
\hline
\end{tabular}

Suppose there are special assignments for the Organization/Division during any quarter of the year, the contribution of that assignment can be added to the organization output. For example, considering the WOV of the special task as 8.0 and weightage of a task carried out as $18 \%$, the output/performance index value of the organization for that quarter will be $7.511 \cdot 0.82+8.0 \cdot 0.18=7.60$ which is rated as highly satisfactory.

Similarly, the annual index numbers for workgroups, sections, departments, and the division can be computed by averaging the quarterly index numbers. Thus, this methodology will help the management in understanding the best performers and laggards for rewards and initiating corrective measures as and when needed. Atypical output performance comparison of workgroups of a section for a quarter for various projects are presented in table 4 and for the different department over all quarters of a year is presented in table 5. Quarterly performance of various works groups and various departments are also shown in figures 3 and 4 .

The annual output performance index of various departments is presented in table 6 as well as in figure 5 .

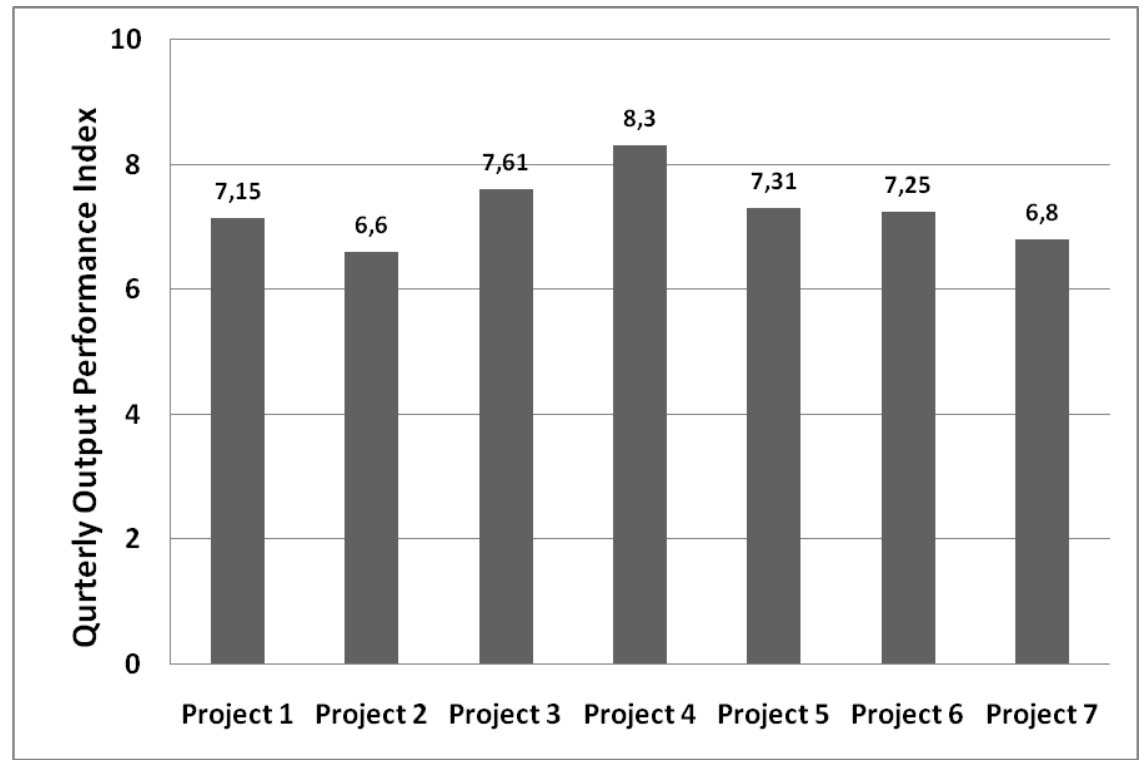

Figure 3: Work Group WOV Quarterly Performance of a Section 
S. K. John

et al.

Table 4: Quarterly Output Performance index of

Work Groups of a Typical Section

\begin{tabular}{|c|c|c|}
\hline No & $\begin{array}{c}\text { Work Groups of } \\
\text { Section }\end{array}$ & $\begin{array}{c}\text { Quarterly WOV } \\
\text { Index numbers }\end{array}$ \\
\hline 1 & Project 1 & 7.15 \\
\hline 2 & Project 2 & 6.60 \\
\hline 3 & Project 3 & 7.61 \\
\hline 4 & Project 4 & 8.30 \\
\hline 5 & Project 5 & 7.31 \\
\hline 6 & Project 6 & 7.25 \\
\hline 7 & Project 7 & 6.80 \\
\hline
\end{tabular}

Table 5: Quarterly Output performance Index Number for various departments

\begin{tabular}{|l|c|c|c|c|c|}
\hline \multicolumn{1}{|c|}{ Department } & Q1 & Q2 & Q3 & Q4 & $\begin{array}{c}\text { Annual Performance } \\
\text { output Index }\end{array}$ \\
\hline Production & 7.163 & 7.236 & 7.282 & 7.174 & 7.213 \\
\hline Planning \& Projects & 6.636 & 6.631 & 6.754 & 6.734 & 6.688 \\
\hline Quality Assurance & 6.894 & 7.098 & 7 & 7.137 & 7.032 \\
\hline Marketing & 6.915 & 6.99 & 6.987 & 7.104 & 6.999 \\
\hline Finance and Accounts & 6.81 & 7.25 & 6.93 & 7.35 & 7.085 \\
\hline Administration & 6.66 & 7.05 & 6.85 & 6.96 & 6.88 \\
\hline Human Resource (HR) & 6.72 & 6.93 & 6.86 & 6.9 & 6.852 \\
\hline
\end{tabular}

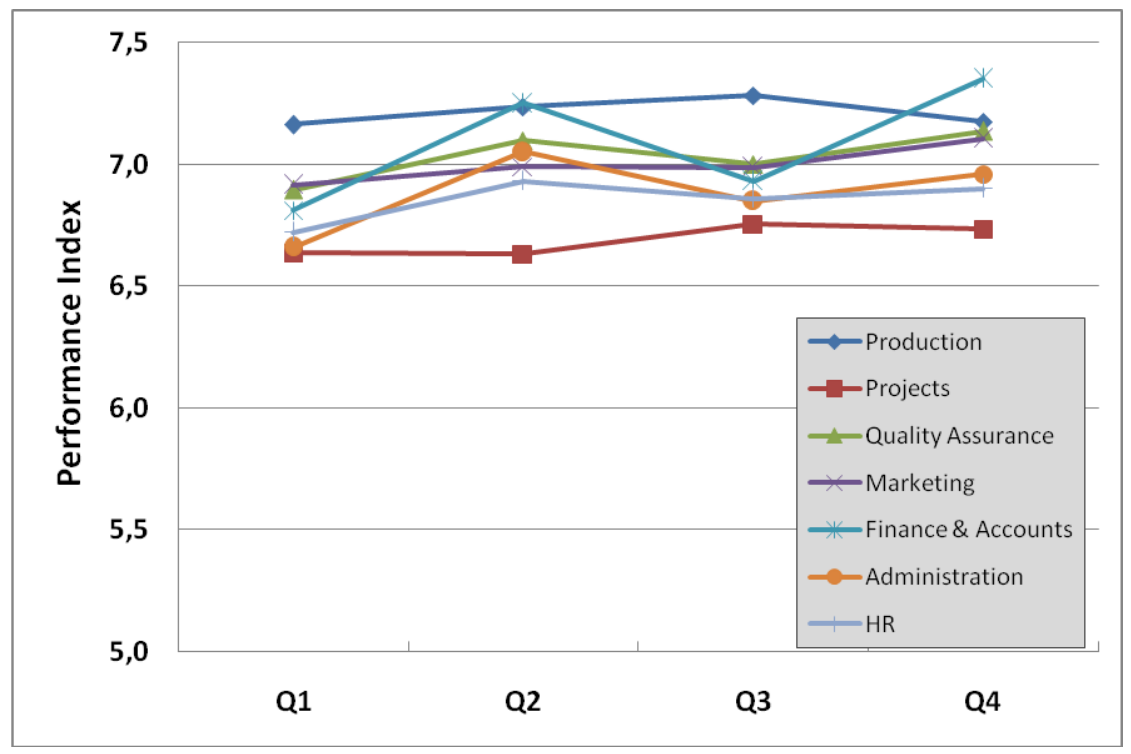

Figure 4: Output Performance Comparison of Departments: Quarter-wise

These figures as well as tables show that the organizational performance or output index numbers can be easily estimated using the novel methodology and model developed in this study. This model proves very useful for the aviation MRO whose case study has been considered here. This model can be extended for a wide range of organizations namely automobile industries, steel and aluminium industries, thermal power plants, and even service-oriented industries considering suitable parameters relevant to the type of industry.
Furthermore, a ready-to-use generalized tool can be developed based on this approach with a menudriven front-end where organizational tasks and their weightages can be interfaced by the policymakers of the organization either directly or through library files. The tool can be an invaluable asset of an organization for evaluation of its overall performance index (Arnett, Laverie, \& McLane, 2002; Cezarino, Junior, \& Correa, 2012). 
Table 6: Annual Output Performance

Index of various departments

\begin{tabular}{|c|l|c|}
\hline No. & \multicolumn{1}{|c|}{ Departments } & $\begin{array}{c}\text { Annual } \\
\text { Output Index }\end{array}$ \\
\hline 1 & Production Department (PD) & 7.213 \\
\hline 2 & Planning and Projects (P\&P) & 6.688 \\
\hline 3 & Quality Assurance (QA) & 7.032 \\
\hline 4 & Marketing (MKT) & 6.999 \\
\hline 5 & Finance and Accounts (F\&A) & 7.085 \\
\hline 6 & Administration (ADM) & 6.88 \\
\hline 7 & Human Resource (HR) & 6.852 \\
\hline
\end{tabular}

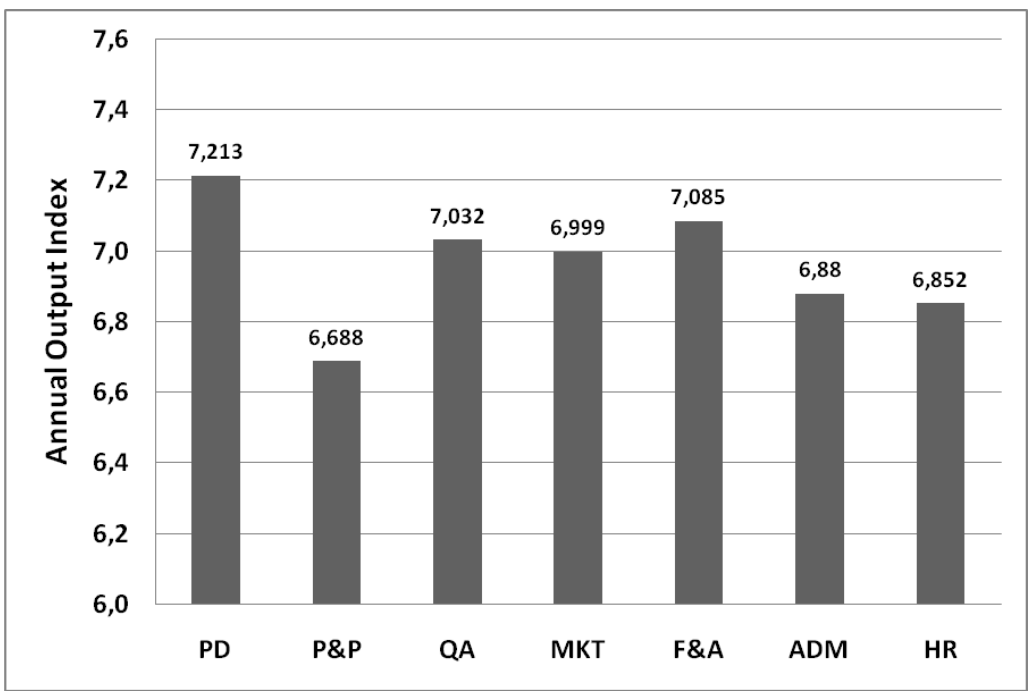

Figure 5: Annual Output Performance Comparison of various Departments

\section{CONCLUSION}

A novel methodology for the measurement of performance index from the lowest organizational hierarchy to the top management level has been presented in this paper. Successful implementation of this model can lead to an excellent work performance measurement tool for the management for assessing the various section and workgroup output performance towards further enhancement of productivity of the division. However for the implementation of the model a suitable customized software package has to be developed as manual computation of data is highly cumbersome and just impossible. This package can be interfaced and integrated with the existing ERP tools available in the industry. Availability of such productivity tool can enhance the productivity of sections and divisions along with acting as an effective Decision Support system (DSS) cum transaction processing system (TPS) cum management information system (MIS) tools. Such a tool can also act as an excellent measure for comparing performance between workgroups, sections, and departments. On successful implementation of the model in an Aviation MRO and Production industry, the model can be extended to other industries with suitable organizational parameters and weightage factors for assessing the organizational performance index.

\section{REFERENCES}

Anderson, T. W. (1985). An Introduction to Multivariate Statistical Analysis. Wiley Pvt Ltd

Arnett, D. B., Laverie, D. A., \& McLane, C. (2002). Using job satisfaction and pride as internalmarketing tools. Cornell Hotel and Restaurant Administration Quarterly, 43(2), 87-96.

Balaboniene, I., \& Vecerskiene, G. (2015). The aspects of performance measurement in the public sector organization. In "International Scientific Conference Economics and Management, ICEM". pp.314-320.

Bonabeau, E., Sobkowski, A., Theraulaz, G., \& Deneubourg, J. L. (1997). Adaptive Task Allocation Inspired by a Model of Division of Labor in Social Insects. In Brisbane Convention \& Exhibition Centre - BCEC pp. 36-45.

Braglia, M., Grassi, A., \& Montanari, R. (2004). Multi-attribute classification method for spare parts inventory management. Journal of Quality in 
Maintenance Engineering, 10(1), 55-65. doi:10.1108/13552510410526875

Brown, M. G. (2017). Baldrige award winning quality: How to interpret the Baldrige criteria for performance excellence. CRC Press.

Cezarino, L. O., Junior, F. H., \& Correa, H. L. (2012). Organization performance evaluation using system thinking: A study in Brazilian chemical organizations models. Systemic Practice and Action Research, 25(1), 81-92. doi:10.1007/s11213-0119198-4

Dose, J. J. (1997). Work values: An integrative framework and illustrative application to organizational socialization. Journal of Occupational and Organizational Psychology, 70(3), 219-240. doi:10.1111/j.20448325.1997.tb00645.x

Garg, B. L., Karadia, R., Agarwal, U. K. (2002). An Introduction to Research Methodology. RBSA Publishers.

Graham, A., Shiba, S., \& Walden, D. (2001). Four practical revolutions in management: Systems for creating unique organizational capability. CRC Press.

Gross, R. (2015). Measuring organizational performance: A new approach to triple bottom line reporting and stakeholder engagement. British Journal of Business and Management Research, 2(1), 69-80. doi: 10.1.1.1061.9920

Hartnell, C. A., Ou, A. Y., \& Kinicki, A. (2011). Organizational culture and organizational effectiveness: A meta-analytic investigation of the competing values framework's theoretical suppositions. Journal of Applied Psychology, 96(4), 677. doi:10.1037/a0021987

Kennedy, R., Jamison, E., Simpson, J., Kumar, P. Kemp, A., Awate, K., \& Manning, K. (2020). Strategic management: Assessing Organizational Performance: Organizational Performance - A Complex Concept. Virginia Tech Publishing.

Kothari, C.R. (1990). Research Methodology, Methods and Techniques. New Age International.

Li, F., Etienne, A., Vernadat, F., \& Siadat, A. (2018). Comprehensive Performance Expression Model for Industrial Performance Management and Decision
Support. IFAC-PapersOnLine, 51(11), 558-563. doi:10.1016/j.ifacol.2018.08.377

Melnyk, S. A., Bititci, U., Platts, K., Tobias, J., \& Andersen, B. (2014). Is performance measurement and management fit for the future?. Management Accounting Research, 25(2), 173-186. doi:10.1016/j.mar.2013.07.007

Monks, J. G. (1987). Operation management. McGrawHill International Editions.

Nair, M. (2004). Essentials of balanced scorecard (Vol. 31). John Wiley \& Sons.

Richard, P. J., Devinney, T. M., Yip, G. S., \& Johnson, G. (2009). Measuring organizational performance: Towards methodological best practice. Journal of Management, 35(3), 718-804. doi:10.1177/0149206308330560

Spekle, R. F., \& Verbeeten, F. H. (2014). The use of performance measurement systems in the public sector: Effects on performance. Management Accounting Research, 25(2), 131-146. doi:10.1016/j.mar.2013.07.004

Stanleigh, M. (2015). Measuring Your Organization's Performance by Business Improvement Architect: International Journal Business Process Management, Employee Engagement, Leadership, Strategy. Business Improvement Architects

Teunter, R. H., Babai, M. Z., \& Syntetos, A. A. (2010). ABC classification: service levels and inventory costs. Production and Operations Management, 19(3), 343-352. doi:10.1111/j.19375956.2009.01098.x

Waggoner, D. B., Neely, A. D., \& Kennerley, M. P. (1999). The forces that shape organisational performance measurement systems: An interdisciplinary review. International Journal of Production Economics, 60, 53-60. doi:10.1016/S0925-5273(98)00201-1

Zhao, Y., Morita, H., \& Maruyama, Y. (2019). The measurement of productive performance with consideration for allocative efficiency. Omega, 89 , 21-39. doi: 10.1016/j.omega.2018.09.012

Zhou, Y. M. (2013). Designing for complexity: Using divisions and hierarchy to manage complex tasks. Organization Science, 24(2), 339-355. doi:10.1287/orsc. 1120.0744 


\section{NOVI KONCEPT KVANTITATIVNOG MERENJA INDEKSA ORGANIZACIONE PERFORMANSE}

Performanse organizacije zavise od mnogih dimenzija tehnologije i upravljanja, poput liderstva, strateškog planiranja, fokusa na kupca, upravljanja procesima, merenja, analize, upravljanja znanjem, troškova, finansijskog upravljanja i upravljanja ljudskim resursima. Međutim, efikasnost organizacije može se lako proceniti na osnovu izlaznih performansi organizacije u odnosu na postavljene ciljeve, dok druge dimenzije deluju kao dodatni katalizatori u maksimiziranju produktivnosti. Stoga merenje ukupnih izlaza (rezultata) organizacije, kao i svih njenih odeljenja u bilo kojoj organizacionoj hijerarhiji, postaje veoma kritično. Nova metodologija kvantitativnog merenja organizacionih izlaza (rezultata) koja kombinuje matematičko i statističko modeliranje pristupa odozdo prema gore razvijena je i objašnjena je u ovom radu. Koncept se može koristiti sa postojećim resursima preduzeća i alatima za planiranje koji su dostupni $\quad$ industrijama za poboljšanje produktivnosti.

Ključne reči: Vrednosti izlaznog rada; Kontrola planiranja proizvodnje; Indeks performansi; Podela zadatka; Težinski faktor 